\title{
Phylogeography and divergence in the chloroplast genome of Western Australian Sandalwood (Santalum spicatum)
}

\author{
M Byrne, B Macdonald and J Brand ${ }^{1}$ \\ Science Division, Department of Conservation and Land Management, Locked Bag 104, Bentley Delivery Centre, WA 6983, Australia
}

\begin{abstract}
Western Australian sandalwood (Santalum spicatum) is widespread throughout Western Australia across the semiarid and arid regions. The diversity and phylogeographic patterns within the chloroplast genome of $S$. spicatum were investigated using restriction fragment length polymorphism analysis of 23 populations. The chloroplast diversity was structured into two main clades that were geographically separated, one centred in the southern (semiarid region) and the other in the northern (arid) region. Fragmentation due to climatic instability was identified as the most likely influence
\end{abstract}

Keywords: sandalwood; cpDNA; phylogeny; phylogeography

\section{Introduction}

There are five species of the genus Santalum endemic to Australia. Of these Santalum spicatum (Western Australian Sandalwood) is found in Western Australia and South Australia, while S. lanceolatum (Plumbush), S. acuminatum (Quandong) and S. murrayanum (Bitter Quandong) are distributed throughout Australia, and S. obtusifolium is confined to the eastern coast (Hewson and George, 1984). The Indian Sandalwood S. album also occurs in Australia in the northern most parts of the Northern Territory. Among the Australian endemic species, only S. spicatum has commercial significance as it produces a sesquiterpene oil similar to S. album (Shea et al, 1998). S. spicatum has been harvested commercially since 1845 and was a primary industry in the early years of European settlement in Western Australia (Loneragan, 1990).

$S$. spicatum occurs across a wide range of environmental conditions as it has a broad distribution throughout the southern semiarid (approximately 300-600 mm rainfall), and northern arid (approximately 150-300 mm rainfall) areas of Western Australia. Morphological variation has been observed across the range suggesting the presence of two ecotypes within the species (Fox and Brand, 1993). In the higher rainfall areas, in the southwest of the distribution, the species shows larger leaves and nuts, has higher chlorophyll content and forms more of a tree habit than in the arid areas in the north and east

Correspondence: M Byrne, Science Division, Department of Conservation and Land Management, Locked Bag 104, Bentley Delivery Centre, WA 6983, Australia. E-mail: margaretb@calm.wa.gov.au

${ }^{1}$ Current address: Forest Products Commission, Locked Bag 888, Perth Business Centre, WA 6849, Australia.

Received: 14 May 2003 on the differentiation of the lineages. The lineage in the arid region showed a greater level of differentiation than that in the southern region, suggesting a higher level of gene flow or a more recent range expansion of sandalwood in the southern region. The phylogeographic pattern in the chloroplast genome is congruent with that detected in the nuclear genome, which identified different genetic influences between the regions and also suggested a more recent expansion of sandalwood in the southern region.

Heredity (2003) 91, 389-395. doi:10.1038/sj.hdy.6800346 of the distribution (Fox and Brand, 1993). Trees in the arid areas also show higher concentrations of oil in the wood (Loneragan, 1990). A genetic study using nuclear restriction fragment length polymorphism (RFLP) markers showed some evidence of differentiation of ecotypes, but it was not significant (Byrne et al, 2003). However, the study did show significant differences in the genetic influences within the two regions, with the northern region showing stable history with equilibrium between drift and gene flow, and the southern region showing no drift-gene flow equilibrium and variances consistent with fragmented, isolated populations under greater influence of drift than gene flow. This pattern of differentiation between the regions may reflect the influences of historic processes.

Analysis of genetic variation in the chloroplast genome allows the elucidation of historical factors influencing genetic variation (Schaal et al, 1998). The reduced effective population size of haploid genomes combined with the restricted nature of gene flow through seed dispersal makes maternally inherited organelle markers more likely to record the effects of population history in present-day genetic patterns than nuclear markers (Ennos et al, 1999). Although contemporary gene flow can also influence the distribution of organelle variation, the pattern of distribution often allows differentiation of the effects of historical factors from those of recent origin (Templeton et al, 1990; Schaal et al, 1998). There are some limitations in the use of cpDNA to investigate phylogeographic patterns in plants due to the often low level of variation within species and the slow rate of evolution compared to animal mitochondrial DNA. However, relatively high levels of cpDNA variation have been found in Australian plants (eg Butcher et al, 1995; Byrne and Macdonald, 2000; Byrne et al, 2002) in comparison to 
other species (Soltis et al, 1992). In addition, the southwest of Western Australia is an ancient landscape that has experienced geological stability with no major glaciation or extinction events, and where the pattern of variation is influenced by historic processes. In particular, climatic instability during the Pleistocene resulting in cyclic expansion and contraction of the mesic and arid zones (Hopper, 1979; Hopper et al, 1996) has led to naturally fragmented population systems with a high level of endemism and both relictual and derived species. Hence, cpDNA analysis has proven useful in determining phylogenetic patterns in plant species in Western Australia, and studies of both widespread species and restricted species with disjunct distributions have revealed the presence of historical lineages that have been differentiated through isolation (Byrne et al, 1999, 2001b, 2002). The presence of two ecotypes in S. spicatum influenced by different genetic processes may represent similar patterns of historic separation in this species.

This study investigates the evolutionary and phylogeographic patterns within $S$. spicatum using RFLP analysis of the chloroplast genome. The mode of inheritance of chloroplasts has not been determined in Santalum but is maternal in most angiosperms (Harris and Ingram, 1991; Birky, 1995).

\section{Materials and methods}

\section{Plant collections}

Leaf samples were collected from 23 populations throughout the main range of $S$. spicatum (Figure 1). Collections were made of 10 individuals from each of the populations. Leaf samples were also collected from 10 individuals in each of two populations of S. acuminatum as outgroups (Figure 1). DNA was extracted from the leaves of the 250 individuals as in Byrne and Moran (1994), with the addition of $0.1 \mathrm{M}$ sodium sulphite to the extraction buffers (Byrne et al, 2001a). DNA quality was good, but the yield was low, probably due to high levels of sesquiterpene oils. Initially, $3 \mu \mathrm{g}$ DNA from five individuals per population was digested with six restriction enzymes (BclI, BglII, EcoRI, EcoRV, HindIII, $\mathrm{XbaI}$ ) and hybridised with heterologous probes covering the majority of the chloroplast genome. Six petunia cpDNA probes were used, P1, P3, P4, P6, P8, P10 (details given in Sytsma and Gottlieb, 1986), plus one tobacco cpDNA probe, pTBa1 (Shinozaki et al, 1986; Suguira et al, 1986). Restriction digestion and hybridisation were as described in Byrne and Moran (1994), and probe plasmids were linearised and then labelled with ${ }^{32} \mathrm{P}$ using the random priming method. After analysis of the data for the first 125 individuals, DNA of the remaining five individuals per population was digested with two of the enzymes (EcoRI and EcoRV) and probe-enzyme combinations for mutations detected in the first 125 individuals were assayed for the second 125 individuals.

\section{Data analysis}

Banding patterns obtained were interpreted in terms of restriction site or length mutations, and assessed as presence or absence of mutations (not presence or absence of bands). Fragment patterns for consecutive chloroplast probes were compared to ensure that each mutation was correctly interpreted and counted only

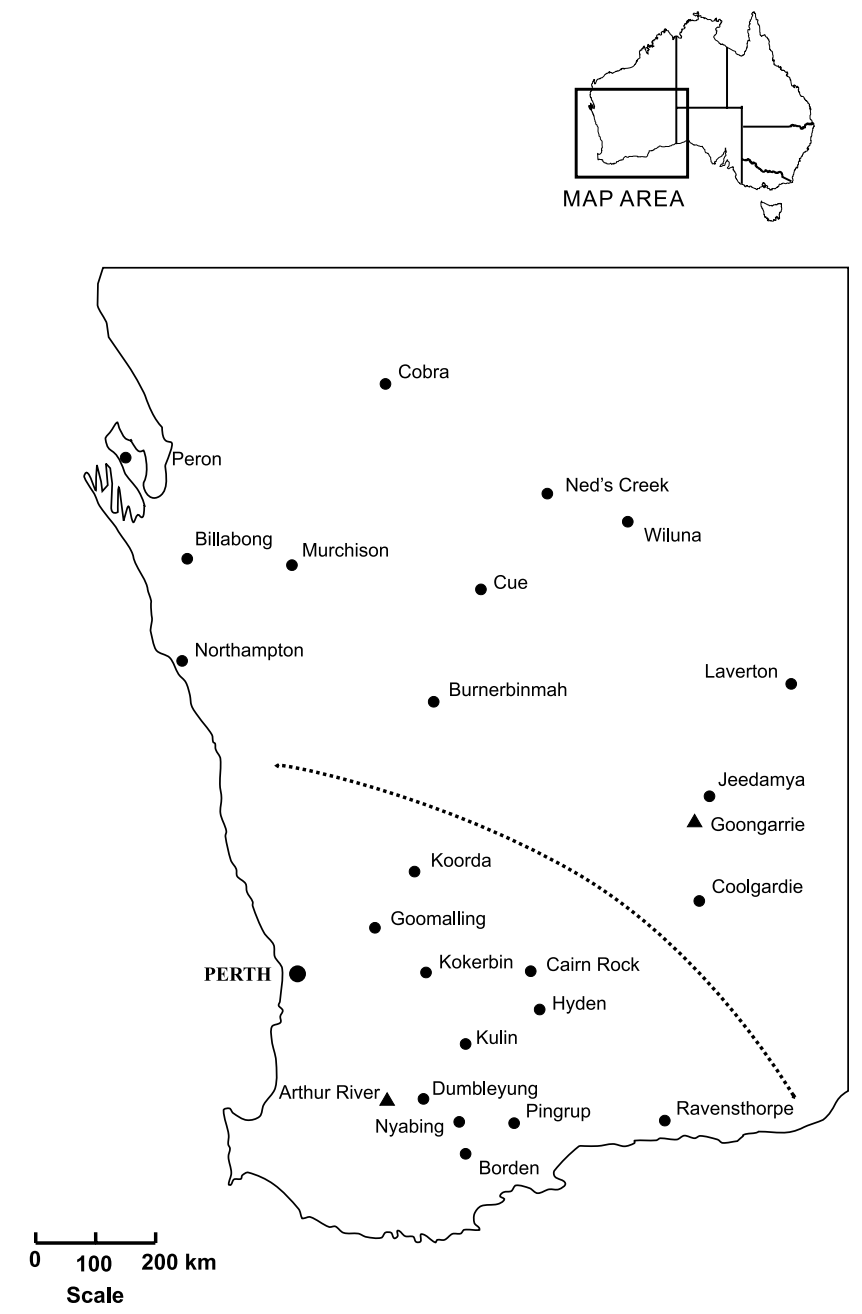

Figure 1 Location of sampled populations of S. spicatum $(\bullet)$ and $S$. acuminatum $(\mathbf{\Delta})$. Dotted line indicates separation of northern and southern regions.

once. Where a length mutation was detected by more than one restriction enzyme it was counted as only one mutation. Nucleotide diversity was calculated for restriction site mutations using HAPLO (Lynch and Crease, 1990), and partitioned within and between populations. Haplotype diversity was calculated by considering haplotypes as alleles at one locus using Nei's (1977) gene diversity measures. A parsimony analysis of haplotype relationships characterised by the presence or absence of each mutation was carried out using PAUP (Swofford, 1991). Bootstrap analysis used 1000 replications and heuristic search with TBR branch swapping and MULPARS on.

To test for the association between phylogenetic position of haplotypes and their geographic distribution, a nested clade analysis (Templeton et al, 1995) was carried out. The nested cladogram was drawn from the PAUP cladogram and parsimony of all connections determined using the program ParsProb (http://bioag.byu.edu/ zoology/crandall_lab/programs.htm) based on algorithms described in Templeton et al (1992). Geographic associations of haplotypes were determined using the program GeoDis (Posada et al, 2000). Interpretation of the nested clade analysis followed the inference key given in Templeton et al (1995). 


\section{Results}

\section{Variation in cpDNA}

This study analysed restriction sites in the chloroplast genome and revealed polymorphism with all enzymes used. Within S. spicatum, 14 mutations were detected; of these, five were restriction site mutations and nine were length mutations (Table 1). Half of the mutations occurred in the small single-copy region and half occurred in the large single-copy region. The first assay of five individuals per population detected the majority of the mutations. The assay of an additional five individuals per population detected one additional mutation (number 14), which was restricted to three individuals from the Billabong population.

The 14 mutations were distributed over 11 haplotypes. One haplotype (B) was more common than all others, occurring in $45 \%$ of the individuals sampled. The remaining haplotypes occurred with frequencies ranging from $2.6 \%$ to $13 \%$. The most common haplotype (B) was present in all southern populations, except Nyabing, and the north-eastern population of Coolgardie. The remaining haplotypes occurred in one to three populations. Intrapopulation variation was present in two populations: Kokerbin in the south had two haplotypes present and Billabong in the north had three haplotypes.

There were 11 mutations that differentiated S. spicatum from the two populations of the related species S. acuminatum, three site mutations and eight length mutations (Table 2). There were also eight mutations detected between the two populations of S. acuminatum, two restriction site mutations and six length mutations. Of these eight mutations, five were shared between the Goongarrie (north-eastern) population of S. acuminatum

Table 1 Restriction fragment length polymorphisms detected in the chloroplast genome of S. spicatum

\begin{tabular}{|c|c|c|c|}
\hline Probe/enzyme & Mutation & Fragment sizes $(k b)$ & Population (individual numbers) \\
\hline 1. pTBa1/HindIII & Site & $5.65=3.35+2.3$ & Northampton, Murchison, Billabong (3) \\
\hline 2. P8/EcoRV & Site & $5.2+2.8=8.0$ & $\begin{array}{l}\text { Burnerbinmah, Goomalling, Hyden, Ravensthorpe, } \\
\text { Pingrup, Cairn, Koorda, Nyabing, Borden, Kulin, } \\
\text { Coolgardie, Dumbleyung, Kokerbin }\end{array}$ \\
\hline 3. P8/EcoRV & Site & $8.0+2.3=10.3$ & Billabong $(1,2,4,5,6,7,8,9,10)$ \\
\hline 4. P6/P10/BclI & Site & $4.5+2.8=7.3$ & $\begin{array}{l}\text { Burnerbinmah, Goomalling, Hyden, Ravensthorpe, } \\
\text { Pingrup, Cairn, Koorda, Nyabing, Borden, Kulin, } \\
\text { Coolgardie, Dumbleyung, Kokerbin }\end{array}$ \\
\hline 5. P1/P4/EcoRV & Site & $9.2+2.2=11.4$ & Peron \\
\hline 6. pTBa1/EcoRI & Length & 2.05 vs 2.5 & $\begin{array}{l}\text { Burnerbinmah, Goomalling, Hyden, Ravensthorpe, } \\
\text { Pingrup, Cairn, Koorda, Nyabing, Borden, Kulin, } \\
\text { Coolgardie Dumbleyung, Kokerbin }\end{array}$ \\
\hline 7. P6/EcoRI & Length & 1.9 vs 1.5 & $\begin{array}{l}\text { Burnerbinmah, Goomalling, Hyden, Ravensthorpe, } \\
\text { Pingrup, Cairn, Koorda, Nyabing, Borden, Kulin, } \\
\text { Coolgardie, Dumbleyung, Kokerbin }(1,2,8,9,10)\end{array}$ \\
\hline 8. P6/EcoRI & Length & 2.55 vs 2.65 & Kokerbin $(3,4,5,6,7)$ \\
\hline 9. P1/P4/BclI & Length & 5.1 vs 7.8 & Northampton, Murchison, Billabong (3) \\
\hline 10. P1/P4/BclI & Length & 9.1 vs 8.8 & Ned's Creek, Cobra, Wiluna \\
\hline 11. P1/P4/BclI & Length & 9.1 vs 8.9 & Nyabing \\
\hline 12. P1/P4/BglII & Length & 2.15 vs 1.95 & Burnerbinmah \\
\hline 13. P1/P4/HindIII & Length & 1.4 vs 0.9 & Northampton, Billabong (3) \\
\hline 14. P1/P4EcoRI & Length & 4.2 vs 3.9 & Billabong $(7,8,9)$ \\
\hline
\end{tabular}

Populations detailed possess the fragment sizes listed second. kb: kilobases.

Table 2 Restriction fragment length variation detected between the chloroplast genomes of S. spicatum and S. acuminatum

\begin{tabular}{|c|c|c|c|}
\hline Probe/enzyme & Mutation & Fragment sizes $(k b)$ & Taxon and population \\
\hline A. $\mathrm{P} 8 / B g l \mathrm{II}$ & Site & $3.2=1.7+1.5$ & S. spicatum \\
\hline B. P8/EcoRV & Site & $15.9=8.0+7.9$ & S. spicatum \\
\hline C. P6/BglII & Site & $7.6+2.5=11.1$ & S. spicatum \\
\hline D. pTBa1/BclI & Length & 3.75 vs 2.65 & S. spicatum \\
\hline E. pTBa1/BglII & Length & 6.5 vs 6.0 & S. spicatum \\
\hline F. pTBa1/EcoRI & Length & 1.5 vs 1.6 & S. spicatum \\
\hline G. P3/BclI & Length & 7.8 vs 5.2 & S. spicatum \\
\hline H. P6/EcoRI & Length & 3.3 vs 2.45 & S. spicatum \\
\hline I. P8/EcoRI & Length & 2.9 vs 3.1 & S. spicatum \\
\hline J. P8/EcoRV & Length & 1.8 vs 2.3 & S. spicatum \\
\hline K. P10/EcoRV & Length & 17.0 vs 8.3 & S. spicatum \\
\hline L. P3/BclI & Length & 3.8 vs 3.5 & S. spicatum, S. acuminatum Goongarrie \\
\hline M. P3/BglII & Length & 2.9 vs 3.9 & S. spicatum, S. acuminatum Goongarrie \\
\hline N. P3/HindIII & Length & 5.1 vs 6.7 & S. spicatum, S. acuminatum Goongarrie \\
\hline O. P8/BclI & Length & 9.2 vs 6.5 & S. spicatum, S. acuminatum Goongarrie \\
\hline P. P8/XbaI & Length & 5.3 vs 4.3 & S. spicatum, S. acuminatum Goongarrie \\
\hline Q. pTBa1/BclI & Length & 3.75 vs 2.8 & S. acuminatum Goongarrie \\
\hline R. P8/XbaI & Site & $5.25=4.0+1.25$ & S. acuminatum Arthur River \\
\hline S. P10/BclI & Site & $6.8+1.6=8.4$ & S. acuminatum Arthur River \\
\hline
\end{tabular}

Taxa detailed possess the fragment sizes listed second. kb: kilobases. 
and all individuals of $S$. spicatum. The other three mutations were specific to either the Goongarrie population or the Arthur River (southern) population of S. acuminatum.

\section{Nucleotide and haplotype diversity}

Nucleotide diversity, the average number of nucleotide differences per site between two sequences (Nei, 1978), can be determined for restriction site but not length mutations. Nucleotide diversity, averaged over all pairs of individuals in S. spicatum was $0.074 \%$. The mean diversity within populations was $0.0001 \%$ and the mean diversity between populations was $0.00096 \%$. The proportion of nucleotide diversity between populations, $N_{\mathrm{ST}}$, was $99 \%$. The mean diversity between lineages (see below) was $0.116 \%$. A measure of haplotype diversity can be determined by treating the whole chloroplast genome as a single locus with each haplotype as an allele. Total haplotype diversity $\left(H_{\mathrm{T}}\right)$ was 0.749 and haplotype diversity within populations $\left(H_{\mathrm{S}}\right)$ was 0.045 . The proportion of haplotype diversity between populations, $G_{\mathrm{ST}}$, was $94 \%$. At the regional level, haplotype diversity $\left(H_{\mathrm{T}}\right)$ in the northern region was 0.836 and diversity between populations, $G_{\mathrm{ST}}$, was $95 \%$, while in the southern region haplotype diversity was lower, $H_{\mathrm{T}}=0.244$, and only $81 \%$ of this diversity occurred between populations.

\section{Haplotype and population relationships}

A phylogenetic parsimony analysis of haplotypes gave one tree of length 32, with a consistency index of 1.0. The cladogram showed all individuals of S. spicatum clustered into a clade clearly differentiated from, and monophyletic in relation to, the outgroup S. acuminatum (Figure 2). Within the S. spicatum clade, the tree shows a star pattern with an unresolved polytomy of six branches representing three clades and three single terminal branches. The most differentiated clade shows structuring of four related haplotypes (A-D) and is characterised by three mutations, with an additional three mutations that differentiate the haplotypes within the clade. The distribution of this clade, which contains the common haplotype (B), includes all of the southern populations plus the northern populations of Burnerbinmah and Coolgardie. Two more clades in the polytomy (with haplotypes $\mathrm{J}-\mathrm{K}$ and $\mathrm{H}-\mathrm{I}$ ) show some structure, being characterised by one to two mutations, and having two haplotypes differentiated by one mutation. These clades occur in the north-west of the distribution. The remaining three branches show little differentiation, characterised by up to one mutation and containing one haplotype each. These branches contain the remaining northern populations. Doubling the number of individuals assayed did not result in a change to the distribution of the mutations among populations and did not change the structure of the phylogenetic tree except for a tip clade in the Billabong population resulting from the additional detection of mutation 14 . Therefore, the sampling of individuals in this study has been sufficient to detect phylogenetic patterns in the chloroplast genome of this species.

A nested clade analysis identified significant geographic structuring in the phylogeny of $S$. spicatum $(P=0.000$; Table 3, Figure 3). All clades showed

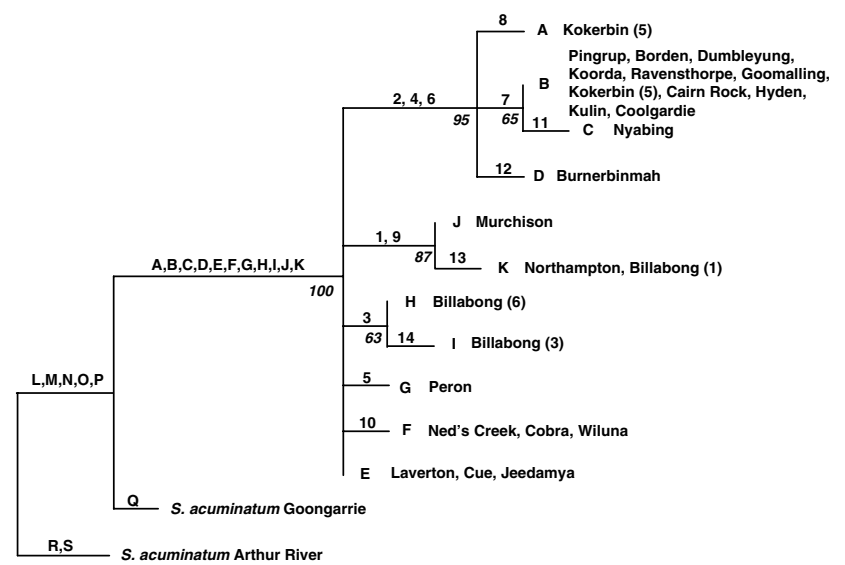

Figure 2 Phylogenetic parsimony tree of haplotype relationships in S. spicatum. Numbers and letters on branches represent mutations (see Tables 1 and 2). Numbers in italics below lines at nodes represent bootstrap confidence values (\%), based on 1000 replications. Numbers in brackets indicate number of individuals in each population with that haplotype.

Table 3 Levels of clade, nested clade and interior-tip distance in clades with significant geographic association in S. spicatum

\begin{tabular}{|c|c|c|c|c|c|}
\hline $\begin{array}{l}\text { Nested } \\
\text { clade }\end{array}$ & Clade/haplotype & $D c$ & Probability & $D n$ & Probability \\
\hline \multirow[t]{3}{*}{ Clade 1-1 } & $\begin{array}{l}\text { Hap b } \\
\text { (interior) }\end{array}$ & 151 & L0.0450 & 499 & 0.0750 \\
\hline & Hap C (tip) & 0.0000 & S0.0000 & 150.9620 & 0.0750 \\
\hline & Interior & 151.7931 & L0.0000 & 36.0122 & 0.0750 \\
\hline \multirow{2}{*}{ Clade 1-2 } & Hap & 00 & 790 & 559 & L0.0010 \\
\hline & Hap & 0.0000 & S0.0010 & 113.6161 & S0.0000 \\
\hline \multirow[t]{3}{*}{ Clade 1-3 } & $\begin{array}{l}\text { Hap J } \\
\text { (interior) }\end{array}$ & 0.0000 & S0.0000 & 99.9913 & S0.0000 \\
\hline & Hap K (tip) & 27.2736 & S0.0000 & 102.3298 & L0.0000 \\
\hline & Interio & -27 & S0.0000 & 385 & S0.0000 \\
\hline \multirow[t]{4}{*}{ Clade 1-4 } & $\begin{array}{l}\text { Hap E } \\
\text { (interior) }\end{array}$ & 207 & 000 & 069 & 0.4330 \\
\hline & Hap G (tip) & 0.0000 & So. & 512.2734 & L0.0000 \\
\hline & Hap F & 191.0068 & 000 & 232. & S0.0010 \\
\hline & Interior $v s$ tip & 63.9803 & 0510 & -6.3662 & 0.4330 \\
\hline \multirow[t]{3}{*}{ Clade 2-1 } & Clad & 147.8 & & & S0.0000 \\
\hline & $\begin{array}{l}\text { Clade 1-2 } \\
\text { (interior) }\end{array}$ & 151.4793 & 0.3080 & 284.5015 & L0.0000 \\
\hline & Interior $v s$ tip & 3.6488 & 0.3550 & 129.4473 & L0.0000 \\
\hline \multirow[t]{4}{*}{ Clade 2-2 } & Clade 1-3 ( & 101.2 & & & S0.0150 \\
\hline & $\begin{array}{l}\text { Clade 1-4 } \\
\text { (interior) }\end{array}$ & 299.8447 & 0.3430 & 323.0370 & L0.0160 \\
\hline & Clade 1-5 & & & $29 ?$ & 0.3790 \\
\hline & Interi & 228.9934 & 000 & 60.9784 & L0.0160 \\
\hline \multirow[t]{3}{*}{ Clade 3} & Clade 2-1 (t & 169.9904 & & 298.3975 & S0.0000 \\
\hline & Clade 2-2 & 304.7435 & S0.0020 & 449.0316 & L0.0000 \\
\hline & Interior $v s$ tip & 134.7531 & L0.0000 & 150.6340 & L0.0000 \\
\hline
\end{tabular}

$\mathrm{Dc}=$ clade distance $($ dispersion$) ; \mathrm{Dn}=$ nested clade distance (displacement); $\mathrm{L}=$ probability of larger than expected value; $\mathrm{S}=$ probability of smaller than expected value. Significant probabilities in bold

significant structuring. Analysis could not be carried out for Clade 1-5 as there was no population variation in the clade. All other one-step and two-step clades identified restricted gene flow through isolation-by- 


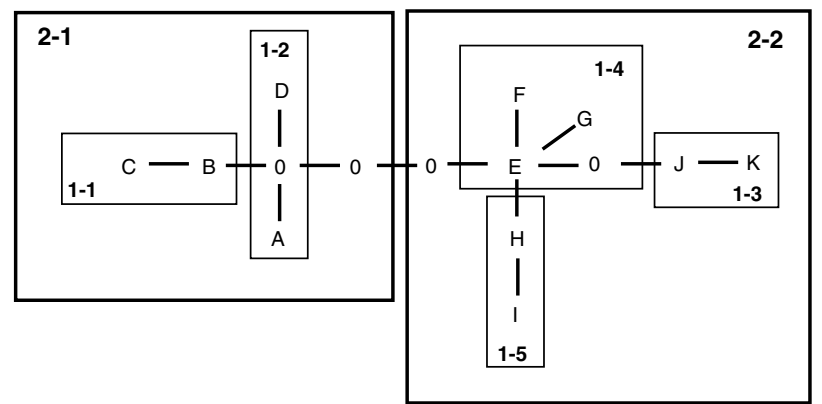

Figure 3 Nested cladogram for haplotypes in S. spicatum. Sampled haplotypes denoted by letters, missing haplotypes denoted by 0 .

Table 4 Phylogeographic inferences from nested clade analysis of $S$. spicatum

\begin{tabular}{lll}
\hline Nested clade & \multicolumn{1}{c}{ Key } & Inference \\
\hline Clade 1-1 & $1,2,3,4$, no & Restricted gene flow \\
Clade 1-2 & $1,2,3,4$, no & Restricted gene flow \\
Clade 1-3 & $1,2,3,4$, no & Restricted gene flow \\
Clade 1-4 & $1,2,5,6,13$, yes & Long-distance colonisation \\
Clade 2-1 & $1,2,3,4$, no & Restricted gene flow \\
Clade 2-2 & $1,2,3,4$, no & Restricted gene flow \\
Clade 3 & $1,2,3,5,15$, no & Past fragmentation \\
\hline
\end{tabular}

Numbers in key refer to options in inference key in Templeton et al (1995).

distance as the main influence on the geographic structuring within these clades, except for Clade 1-4 where an inference of long-distance colonisation was made (Table 4). At the highest nesting level, past fragmentation was identified as the main influence on the geographic structuring between the two-step clades. These two clades are geographically separated, with Clade 2-1 containing haplotypes characterising the southern populations and Clade 2-2 containing haplotypes characterising the northern populations, except for the Burnerbinmah population, which contains haplotypes nested in Clade 2-1. The two clades are also separated by a higher than average number of mutational steps. Clade 2-1 is equivalent to the differentiated clade containing haplotyes $\mathrm{A}$ to $\mathrm{D}$ in the parsimony analysis and Clade 2-2 is equivalent to the remaining branches in the parsimony analysis (Figure 2).

\section{Discussion}

The level of diversity in the chloroplast genome of $S$. spicatum is high compared to other woody perennials but not as high as has been identified in other Australian tree species, including the main host of S. spicatum, Acacia acuminata (Byrne et al, 2002). Significant structuring of the diversity occurs with two main clades that are geographically separated, one centred on the southern region and one centred in the north of the distribution. This differentiation of two lineages is consistent with the identification of differences between the regions in the influence of genetic processes on the nuclear genome (Byrne et al, 2003). It is also consistent with the identification of two ecotypes in these regions, based be used to estimate the time of separation between lineages, although these estimates should be treated as broad indicators due to the assumptions involved (Rieseberg et al, 1991). For the chloroplast genome, it is estimated that $0.1 \%$ divergence represents 1 million years separation (Zurawski et al, 1984). Using this estimate, the time of divergence between the two lineages is around one million years ago, in the middle of the Pleistocene era. Geographical structuring due to historical isolation has also been observed in a common host of S. spicatum, A. acuminata (Byrne et al, 2002) with a similar time frame for the divergence between lineages (approximately 800000 years BP). The identification of similar phylogeographic patterns over similar time frames suggests that they have occurred through the influences of broad biogeographic processes. The isolation and differentiation of lineages observed within S. spicatum, and other species that have been investigated (Byrne et al, 1999, $2001 b, 2002)$, is consistent with the hypothesis that cyclic contraction and expansion of the arid region in the northeast, and the mesic region in the south-west, during the Pleistocene era led to fragmentation and isolation in the intermediate area between the arid and mesic zones (Hopper, 1979; Hopper et al, 1996). Comparative phylogeographic studies in other parts of the world have also demonstrated broad biogeographic influences, including common postglacial colonisation routes in Europe (Ferris et al, 1993, 1998; Demesure et al, 1996; Dumolin-Lapègue et al, 1997; King and Ferris, 1998) and northern and southern glacial refugia in the Pacific North West of America (Soltis et al, 1997).

There were differences in the level of differentiation within the two lineages in S. spicatum. The southern lineage had high similarity within the lineage with low haplotype diversity and the majority of the populations having one of the four haplotypes present in the lineage. In comparison, the northern lineage had greater diversity within the lineage, with greater differentiation between populations and the six haplotypes having lower frequencies and being distributed into three main areas of geographical diversity. This could be an artefact due to the geographically closer sampling of populations in the south compared to the north. However, this reflects patterns of abundance although the distribution in the southern region has been influenced by land clearing for agriculture. There are no direct comparisons of abundance of S. spicatum in the southern and northern regions at the time of settlement. However, the tonnage of sandalwood harvested from the southern region in the early years of settlement indicates that the species abundance was greater than the current abundance in the northern region. Higher abundance and more continuous distribution would lead to greater gene flow and hence less differentiation between populations in the south. The seeds of $S$. spicatum are large nuts, which would result in low dispersal, although emus (Dromaius novaehollandiae) are known to eat the seeds and would be a means of seed dispersal. Havel (1993) hypothesised that the woylie (Bettongia penicillata), a small mammal, may have cached seeds, which would also increase dispersal. Emus and woylies were likely to have been more abundant in the southern region due to higher abundance of food source and may have led to greater seed dispersal in the south than in the north. The greater 
similarity of the southern populations could also indicate a more recent establishment of $S$. spicatum in this region compared to the north. Coalescent theory predicts that ancestral haplotypes have greatest mutational connections and are geographically widespread, but range expansion can lead to younger tip haplotypes also being geographically widespread (see Templeton et al, 1995). The southern clade is a tip clade and the northern clade is the interior clade containing the most likely ancestral haplotype (E). The southern clade being a geographically widespread tip clade is a pattern indicative of population range expansion in the southern region.

The genetic patterns in the chloroplast data are both concordant and discordant with the patterns identified in the nuclear genome. Genetic analysis of the nuclear genome identified an equilibrium between drift and gene flow in the northern region indicating that the region had existed under stable conditions of dispersal for a long period of time (Byrne et al, 2003). In contrast, the southern region showed a genetic pattern indicating that the populations have been more recently established, and that they have been fragmented and influenced to a greater degree by genetic drift than by gene flow. The southern region also showed greater differentiation between populations than those in the northern region. The genetic patterns in the nuclear and chloroplast genomes both suggest that the southern populations have been established more recently than the northern populations. However, the nuclear genome showed greater differentiation in southern populations (southern $\theta=0.108$, northern $\theta=0.055$; Byrne et al, 2003), whereas the chloroplast genome identified greater differentiation in the northern populations (northern $G_{\mathrm{ST}}=95 \%$, southern $G_{\mathrm{ST}}=81 \%$ ). This suggests that the lower differentiation in the chloroplast genome is not likely to be a result of population sampling, higher seed dispersal or greater abundance, but may be due to less time for fragmentation to influence divergence.

\section{Acknowledgements}

We thank the Forest Products Commission of Western Australia for funding this study.

\section{References}

Birky CW (1995). Uniparental inheritance of mitochondrial and chloroplast genes, mechanisms and evolution. Proc Natl Acad Sci USA 92: 11331-11338.

Butcher PA, Byrne M, Moran GF (1995). Variation within and among the chloroplast genomes of Melaleuca alternifolia and M. linariifolia (Myrtaceae). Plant Syst Evol 194: 69-81.

Byrne M, Macdonald B (2000). Phylogeography and conservation of three oil mallee taxa, Eucalyptus kochii ssp kochii, ssp plenissima and E. horistes. Aust J Bot 48: 305-312.

Byrne M, Macdonald B, Broadhurst L, Brand J (2003). Genetic diversity in Australian Sandalwood (Santalum spicatum) as revealed by nuclear RFLP analysis. Theor Appl Genet (in press).

Byrne M, Macdonald B, Coates D (1999). Divergence in the chloroplast genome and nuclear rDNA of the rare Western Australian plant Lambertia orbifolia Gardner (Proteaceae). Mol Ecol 8: 1789-1796.

Byrne M, Macdonald B, Coates D (2002). Phylogeographic patterns in chloroplast DNA variation within the Acacia acuminata (Leguminosae: Mimosoideae) complex in Western Australia. J Evol Biol 15: 576-587.
Byrne M, Macdonald B, Francki M (2001a). Incorporation of sodium sulphite into extraction protocol minimizes degradation of Acacia DNA. BioTechniques 30: 742-744.

Byrne M, Moran GF (1994). Population divergence in the chloroplast genome of Eucalyptus nitens. Heredity 73: 18-28.

Byrne M, Tischler G, Macdonald B, Coates DJ, McComb J (2001b). Phylogentic relationships between two rare acacias and their common widespread relatives in south-western Australia. Cons Gen 2: 157-166.

Demesure B, Comp B, Petit RJ (1996). Chloroplast DNA phylogeography of the common beech (Fagus sylvatica L.) in Europe. Evolution 50: 2515-2520.

Dumolin-Lapègue $S$, Demesure B, Fineschi S, Le Corre V, Petit RJ (1997). Phylogeographic structure of white oaks throughout the European Continent. Genetics 146: 1475-1487.

Ennos RA, Sinclair WT, Hu X-S, Langdon A (1999). Using organelle markers to elucidate the history, ecology and evolution of plant populations. In: Hollingsworth PM, Bateman RM, Gornall RJ (eds) Molecular Systematics and Plant Evolution. Taylor \& Francis: London. pp 1-19.

Ferris C, Oliver RP, Davy AJ, Hewitt GM (1993). Native oak chloroplasts reveal an ancient divide across Europe. Mol Ecol 2: 337-344.

Ferris C, King RA, Väinölä R, Hewitt GM (1998). Chloroplast DNA recognizes three refugia sources of European oaks and suggests independent eastern and western immigrations to Finland. Heredity 80: 584-593.

Fox JED, Brand JE (1993). Preliminary observations on ecotypic variation in Santalum spicatum 1. Phenotypic variation. Mulga Res J 11: 1-12.

Harris SA, Ingram R (1991). Chloroplast DNA and biosystematics: the effects of intraspecific diversity and plastid transmission. Taxon 40: 393-412.

Havel JJ (1993). Review of research needs of the sandalwood industry in Western Australia. Department of Conservation and Land Management, Western Australia.

Hewson HJ, George AS (1984). Flora of Australia. Australian Government Publishing Service: Canberra. Vol 22, pp 61-66.

Hopper SD (1979). Biogeographical aspects of speciation in the southwest Australian flora. Ann Rev Ecol Syst 19: 399-422.

Hopper SD, Harvey MS, Chappill JA, Main AR, Main BY (1996). The Western Australian biota as Gondwanan heritage - a review. In: Hopper SD, Chappill JA, Harvey MS, George AS (eds) Gondwanan Heritage. Past present and Future of the Western Australian Biota. Surrey Beatty \& Sons: Chipping Norton. pp 1-46.

King RA, Ferris C (1998). Chloroplast DNA phylogeography of Alnus glutinosa (L.) Gaertn. Mol Ecol 7: 1151-1161.

Loneragan OW (1990). Historical review of Sandalwood. (Santalum spicatum): research in Western Australia. Research Bulletin No. 4. Department of Conservation and Land Management, Perth.

Lynch M, Crease TJ (1990). The analysis of population survey data on DNA sequence variation. Mol Biol Evol 7: 377-394.

Nei M (1977). F-statistics and analysis of gene diversity in subdivided populations. Ann Hum Genet 41: 225-233.

Nei M (1978). Estimation of average heterozygosity and genetic distance from a small number of individuals. Genetics 89: 583-590.

Posada D, Crandall KA, Templeton AR (2000). GeoDis: a program for the cladistic nested analysis of the geographical distribution of genetic haplotypes. Mol Ecol 9: 487-488.

Rieseberg LH, Beckstrom-Sternberg SM, Liston A, Arias DM (1991). Phylogenetic and systematic inferences from chloroplast DNA and isozyme variation in Helianthus sect. Helianthus (Asteraceae). Syst Bot 16: 50-76.

Schaal BA, Hayworth DA, Olsen KM, Rauscher JT, Smith WA (1998). Phylogeographic studies in plants: problems and prospects. Mol Ecol 7: 465-474. 
Shea SR, Radomiljac A, Brand J, Jones P (1998). An overview of sandalwood and the development of sandal in farm forestry in Western Australia. In: Radomiljac AM, Ananthapadmanabho HS, Welbourn RM, Satyanarayana Rao K (eds). Sandal and It's Products. ACIAR: Canberra. pp 9-15.

Shinozaki K, Ohme M, Tanaka M, Wakasugi T, Hayashiuda N, Matsubayashi T et al (1986). The complete nucleotide sequence of the tobacco chloroplast genome: its gene organization and expression. EMBO J 5: 2043-2049.

Soltis DE, Gitzendanner MA, Strenge DD, Soltis PS (1997). Chloroplast DNA intraspecific phylogeography of plants from the Pacific Northwest of North America. Plant Syst Evol 206: 353-373.

Soltis DE, Soltis PS, Milligan BG (1992). Intraspecific chloroplast DNA variation: systematic and phylogenetic implications. In: Soltis PS, Soltis DE, Doyle JJ (eds). Molecular Systematics of Plants. Chapman \& Hall: New York. pp 117-150.

Suguira M, Shinozaki K, Zaita N, Kusuda M, Kumano M (1986). Clone bank of the tobacco (Nicotiana tabacum) chloroplast genome as a set of overlapping restriction endonuclease fragments: mapping of eleven ribosomal protein genes. Plant Sci 44: 211-216.
Swofford DL (1991). PAUP: Phylogenetic Analysis Using Parsimony. Version 3.1.1. Illinois Natural History Survey, Champaign, IL.

Sytsma KJ, Gottlieb LD (1986). Chloroplast DNA evolution and phylogenetic relationships in Clarkia sect. Peripetasma (Onagraceae). Evolution 40: 1248-1261.

Templeton AR, Crandall KA, Sing CF (1992). A cladistic analysis of phenotypic associations with haplotypes inferred from restriction mapping and DNA sequence data. III. Cladogram estimation. Genetics 132: 619-633.

Templeton AR, Routman E, Phillips CA (1995). Separating population structure from population history: a cladistic analysis of the geographical distribution of mitochondrial haplotypes in the tiger salamander, Ambystoma tigrinum. Genetics 140: 767-782

Templeton AR, Shaw K, Routman E, Davis SK (1990). The genetic consequences of habitat fragmentation. Ann $\mathrm{M} \mathrm{Bot}$ Gard 77: 13-27.

Zurawski G, Clegg MT, Brown AHD (1984). The nature of nucleotide sequence divergence between barley and maize chloroplast DNA. Genetics 106: 735-749. 